\title{
High resolution study of the platelet ice ecosystem in McMurdo Sound, Antarctica: biomass, nutrient, and production profiles within a dense microalgal bloom
}

\author{
Kevin R. Arrigo ${ }^{1, *}$, Gerhard Dieckmann ${ }^{2}$, Michel Gosselin ${ }^{3}$, Dale H. Robinson ${ }^{2}$, \\ Christian H. Fritsen ${ }^{4}$, Cornelius W. Sullivan ${ }^{4,5}$
}

${ }^{1}$ National Aeronautics and Space Administration, Goddard Space Flight Center, Oceans and Ice Branch, Greenbelt, Maryland 20771, USA

${ }^{2}$ Alfred-Wegener-Institut für Polar- und Meeresforschung, Columbusstrasse, D-27570 Bremerhaven, Germany

${ }^{3}$ Départment d'océanographie, Universite' du Quebec à Rimouski, 310 Aleé des Ursulines, Rimouski, Québec, Canada GL5 $3 \mathrm{~A} 1$

${ }^{4}$ Department of Biological Sciences, University of Southern California, Los Angeles, California 90080-0371, USA

${ }^{5}$ National Science Foundation, Office of Polar Programs, 4201 Wilson Blvd, Rm 755, Arlington, Virginia 22230, USA

\begin{abstract}
Vertical distributions of inorganic nutrients (nitrate, nitrite, ammonium, phosphate, and silicic acid) and microalgal and bacterial biomass were monitored within both the lower congelation ice and the platelet ice layer in McMurdo Sound, Antarctica from 31 October to 3 December 1989. Profiles of dissolved organic matter (DOM) (amino acids and simple sugars) and heterotrophic protists were also obtained in early December. Microalgal standing crop increased from 9.4 to $37.4 \mathrm{~g} \mathrm{C} \mathrm{m}^{-2}$ during our $34 \mathrm{~d}$ study (peak accumulation rate of $>1 \mathrm{~g} \mathrm{C} \mathrm{m}^{-2} \mathrm{~d}^{-1}$ ), and maximum pigment concentrations ex-

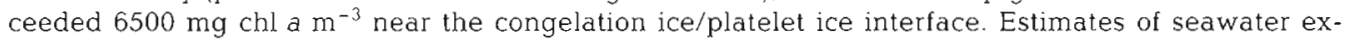
change within the platelet ice ranged from 0.06 to $0.61 \mathrm{~m}^{2} \mathrm{~d}^{-1}$ when $\mathrm{Si}(\mathrm{OH})_{4}$ was used as a tracer. The biochemical composition of the autotrophic community and the presence of high nutrient concentrations within the platelet layer indicated that the growth of platelet ice algae was limited by light, rather than nutrients, throughout the season. $\mathrm{NO}_{3}$ and $\mathrm{Si}(\mathrm{OH})_{4}$ concentrations in the platelet ice were generally high ( 30 to 32 and 65 to $82 \mathrm{mmol} \mathrm{m}^{-3}$, respectively), but became depleted in the uppermost layers as chl a peaked late in November. $\mathrm{NH}_{4}$ was far more abundant in the platelet ice (5 to $10 \mathrm{mmol} \mathrm{m}{ }^{-3}$ ) than in the underlying water column $\left(0.5 \mathrm{mmol} \mathrm{m}^{-3}\right)$ throughout the field season. Microbial regeneration was primarily responsible for the high background concentrations of $\mathrm{NH}_{4}$ in the platelet ice, although physical processes also may have contributed. A large $\mathrm{NH}_{4}$ pulse $\left(>150 \mathrm{mmol} \mathrm{m}^{-3}\right)$ was observed in the platelet layer in early November, possibly attributable to an isolated macrozooplankton grazing and excretion event. $\mathrm{PO}_{4}$ concentrations $\left(2.0 \mathrm{mmol} \mathrm{m}{ }^{-3}\right.$ in the water column) were minimal $\left(<1.7 \mathrm{mmol} \mathrm{m}^{-3}\right)$ in the upper platelet ice on November 11, but began to increase thereafter due to $\mathrm{PO}_{4}$

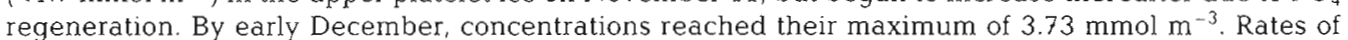
$\mathrm{PO}_{4}$ regeneration were highest (peak of $35 \mathrm{mmol} \mathrm{m}{ }^{-3} \mathrm{~d}^{-1}$ ) in the upper layers of the platelet ice where the bulk of the microbial biomass was located. The platelet ice was unusual because, although concentrations of regenerated nutrients were often high, the elemental composition of particulates remained near the Redfield ratios and detrital abundance was low. The coincidence of $\mathrm{NO}_{2}$ and $\mathrm{NO}_{3}$ peaks at a depth of 0.65 to $0.75 \mathrm{~m}$ suggests that bacterial nitrification may also occur in the platelet ice.
\end{abstract}

KEY WORDS: Antarctic $\cdot$ Platelet ice $\cdot$ Nutrient cycling

\section{INTRODUCTION}

A semi-consolidated layer of platelet ice ranging from a few $\mathrm{cm}$ to several meters in thickness is commonly observed beneath sea ice in regions adjacent to

·E-mail: kevin@shark.gsfc.nasa.gov floating ice shelves (Dayton et al. 1969, Sullivan \& Palmisano 1984, Garrison et al. 1986, Smetacek et al. 1992). Platelet ice consists of a semi-rigid lattice of flat, apparently randomly oriented, disk-shaped ice crystals that are up to $0.10 \mathrm{~m}$ in diameter and a few mm thick. The platelet layer is composed of approximately $20 \%$ ice and $80 \%$ seawater by volume (Bunt 1964). 
Although the regional distribution of this ice type within the Southern Ocean has not yet been quantified, $45 \%$ of the Antarctic continental margin is associated to some degree with an ice shelf (Bindschadler 1990, Kipfstuhl 1991), suggesting that platelet ice may be quite common.

Previous studies have determined the net seasonal production within these communities through several vernal growing seasons (Grossi et al. 1987. Kottmeier et al. 1987. Arrigo et al. 1993a, b), however, the stratification and rates of vertical material/nutrient exchange supporting the vernal blooms have not yet been qualitatively or quantitatively described in the literature. This is unfortunate because platelet ice often is a site of high algal production and biomass accumulation, both in the Weddell (Smetacek et al. 1992) and the Ross Seas (Grossi et al. 1987, Kottmeier et al. 1987. Arrigo et al. 1993b). In both structure and position, platelet ice is intermediate between the relatively impermeable congelation ice above and the more fluid water column below. Like congelation ice, the platelet layer offers a stable surface for algal attachment, photoacclimation (Arrigo et al. 1993b), and growth, but without the steep gradients in temperature and salinity characteristic of congelation ice (Kottmeier \& Sullivan 1988). In addition, because nutrients originating in seawater must pass through the lower portion of the platelet ice layer before reaching the algal assemblage in the upper layers of the platelet ice and the skeletal layer of the congelation ice, its relatively open crystal structure must facilitate some seawater exchange (Smetacek et al. 1992), especially when compared to fluxes measured in the congelation ice (Eide \& Martin 1975, Reeburgh 1984). The combination of a stable substrate, large surface area, and potential for seawater exchange within the platelet ice may be primarily responsible for the dense microbial blooms observed therein, where productivity and biomass accumulation often exceed values observed in both the congelation ice and the water column (Grossi et al. 1987, Arrigo et al. 1993b).

The purpose of this paper is to describe the temporal changes in the vertical distributions of nutrients and microbial biomass within the platelet ice system during the most intense vernal bloom studied to date. From information on the vertical stratification of the platelet ice system we infer rates of vertical nutrient exchange, biological uptake and regeneration. A previous manuscript of ours (Arrigo et al. 1993b) focussed on the bio-optical and photophysiological aspects of this ecosystem during this same study. Here we emphasize temporal changes in nutrient profiles and the vertical distributions of dissolved organic material (DOM, i.e. sugars and amino acids), bacteria, microalgae, and protists within the platelet ice ecosystem.

\section{MATERIALS AND METHODS}

Our main sampling site (IF: Ice Falls) was located in McMurdo Sound, Antarctica, approximately $3 \mathrm{~km}$ north of McMurdo Station ( $77^{\circ} 49.48^{\prime} \mathrm{S}, 166^{\circ} 41.45^{\prime} \mathrm{E}$ ) (Fig. 1). Ice cover consisted of second year congelation ice approximately $2.5 \mathrm{~m}$ thick with a 0.65 to $0.75 \mathrm{~m}$ thick layer of platelet ice below. Snow cover in the region ranged from 0 to $0.10 \mathrm{~m}$, although sampling was concentrated in clear ice areas which dominated the western side of McMurdo Sound in 1989. Sampling took place at 1 to $5 \mathrm{~d}$ intervals starting October 31 , 1989 and ending December 3, 1989, with all sampling conducted within a $200 \mathrm{~m}^{2}$ study site. A secondary site (RW: Ice Runway), chosen for its thick snow cover $(>0.4 \mathrm{~m})$ and consequent reduced photoautotrophic activity, was located approximately $3 \mathrm{~km}$ west of Site IF. Ice cover at this site consisted of second year congelation ice approximately $4.0 \mathrm{~m}$ thick with a $1.0 \mathrm{~m}$ thick layer of platelet ice below.

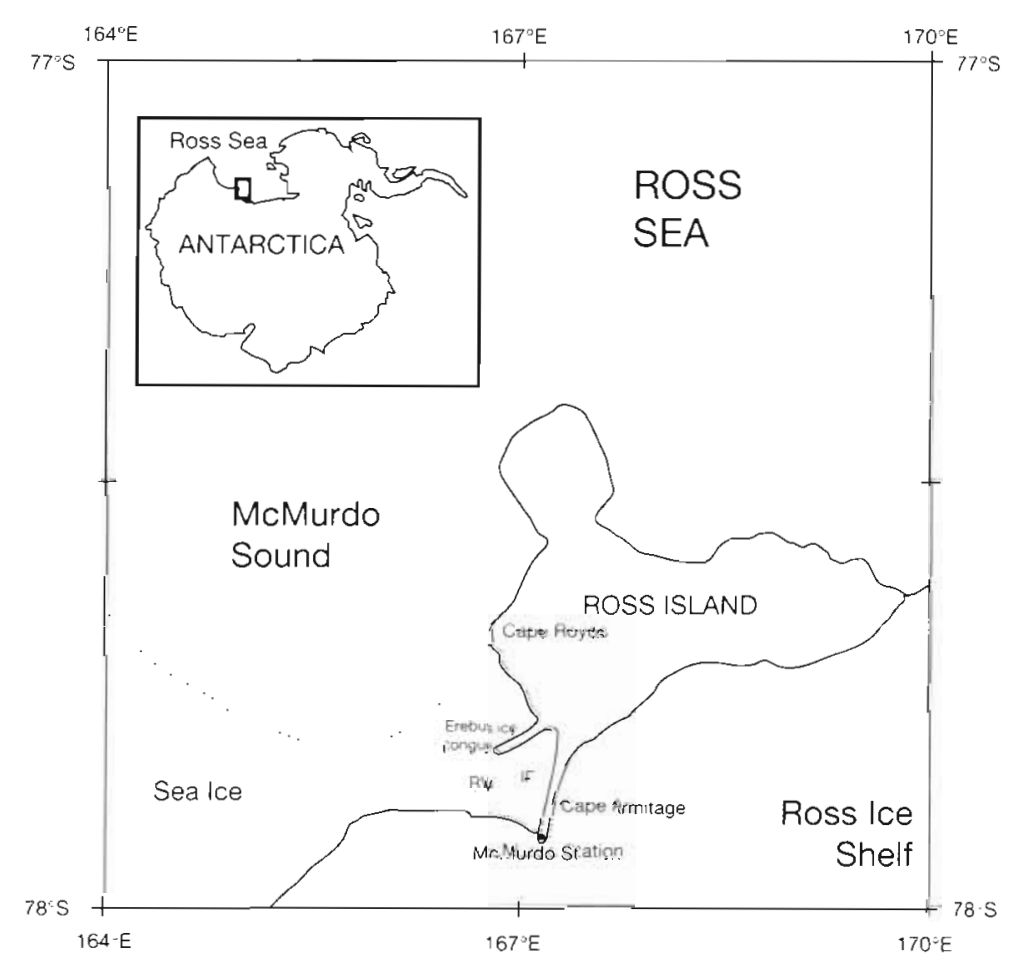

Fig. 1. Study sites monitored in the austral spring of 1989. IF- sampling site characterized by low snow cover $(0$ to $0.1 \mathrm{~m}$ ) and by high biological activity; RW: site which was covered by a $0.4 \mathrm{~m}$ thick layer of snow and where photoautotrophic activity was low 
A recently developed sampling device, ADONIS (Dieckmann et al. 1992), was used to collect interstitial water samples from discrete depths at $0.125 \mathrm{~m}$ intervals within the platelet layer and underlying water column near the ice/seawater interface. Samples were analyzed for inorganic nutrients (silicic acid, nitrate, nitrite, ammonium, and phosphate) and chlorophyll a (chl a) as described by Dieckmann et al. (1992).

Although effective for obtaining accurate profiles of most seawater constituents, concentrations of chl a, bacteria, and protists obtained using ADONIS are underestimates of levels contained within the platelet layer because only interstitial water was sampled and a fraction of sea ice biota adhere to the ice crystal surfaces (Sullivan unpubl.). However, assuming a constant fraction of the total microbial population was collected at each depth, ADONIS provides valuable information about vertical distributions within the platelet layer (Dieckmann et al. 1992, Arrigo et al. 1993b).

Chl $a$ and phaeopigment concentrations were assayed using the method of Parsons et al. (1984). The depth-integrated standing crop of chl a within the platelet layer $\left(C_{p}, \mathrm{mg} \mathrm{m}^{-2}\right)$ was determined as described by Arrigo et al. (1993b). $C_{p}$ was multiplied by the fraction of total chl a in each layer (as determined by ADONIS) to obtain the true chl a concentration at a given depth $i$ according to the equation:

$$
\operatorname{chl} a(i)=\frac{C_{p} f(i)}{z}
$$

where $f$ is the fraction of total biomass at depth $i$ determined from ADONIS chl a profiles, and $z$ is the layer thickness $(0.125 \mathrm{~m})$ at depth $i$ as dictated by the profiling interval.

Unfiltered biological samples containing bacteria and protists were collected using ADONIS and $20 \mathrm{ml}$ subsamples were preserved in $1 \%$ gluteraldehyde. Bacteria were counted using the standard acridine orange direct count method (Hobbie et al. 1977) and converted to carbon units using the calculated mean biovolume of $0.49{\mu \mathrm{m}^{3} \text { cell }}^{-1}$ and a carbon content of

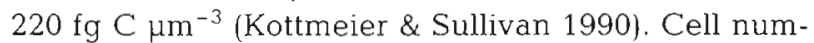
bers, biovolume, and biomass of heterotrophic protists were determined as described in Stoecker et al. (1992).

Interstitial water samples from the platelet ice were filtered (on Whatman GF/F except for Si samples which were filtered on 0.2 Nuclepore filters) and cellular content of $\mathrm{N}, \mathrm{P}$, and Si for ice algae were assayed according to methods described in Parsons et al. (1984). CHN analysis was performed on a Control Equipment Corporation Model 240XA CHN analyzer with a precision of \pm 0.3 weight \% or better. CHN samples were collected on precombusted Whatman GF/F, dried and finely ground. Samples were combusted in an oxygen enriched helium atmosphere and the combustion products analyzed for 5 min with 3 pairs of thermal conductivity detectors. Concentrations of sugars were determined by high performance liquid chromatography (HPLC) and pulsed amperometric detection as described by Mopper et al. (1992). Amino acids were assayed by HPLC according to the method of Lindroth \& Mopper (1979).

Daily rates of microalgal biomass accumulation at a given depth within the platelet layer were estimated from seasonal changes in microalgal standing crop at that depth (i.e. the increase in microalgal carbon between consecutive sampling dates was divided by the number of days between sampling dates). This represents a conservative estimate of new production because losses of algal biomass from the platelet ice layer (probably minimal) are not accounted for.

Rates of seawater exchange $\left(\Gamma, \mathrm{m}^{2} \mathrm{~d}^{-1}\right)$ within the platelet ice layer at Site IF were approximated with a bulk transport model using either $\mathrm{Si}(\mathrm{OH})_{4}$ or $\mathrm{NO}_{3}$ as nutrient tracers. Vertically integrated rates of nutrient uptake by ice microalgae were estimated from temporal changes in integrated $\mathrm{chl} a$ and the chl $a$ : nutrient ratio measured for the ice flora. Again it should be noted that estimates of nutrient uptake based on rates of biomass accumulation are underestimates of actual rates because grazing and sinking losses from the platelet ice layer, although expected to be small, were not accounted for. An advantage of estimating nutrient uptake using temporal changes in accumulated biomass is that the estimate is not sensitive to the presence and uptake of regenerated or remineralized nutrients. This is because biomass cannot accumulate when growing on a regenerated nutrient source. Depth-dependent nutrient uptake rates were calculated from estimates of integrated nutrient uptake by weighting the rate at each depth according to the mean percentage of integrated $\mathrm{chl}$ a contained therein.

According to the bulk transport model used here, the rate of change in the concentration of nutrient $X(\mathrm{mmol}$ $\mathrm{m}^{-3}$ ) at level $i$ within an $n$-layered platelet ice sheet is equal to the sum of the rate of transport of $X$ and the rates of all other processes which alter the abundance of $X$ in layer $i$. Therefore,

$$
\frac{\partial X(i)}{\partial t}=\Gamma \frac{\partial^{2} X(i)}{\partial z^{2}}-U(i)+P(i)
$$

where $t$ is time, $z$ is the thickness of layer $i(0.125 \mathrm{~m})$, and $U$ and $P$ are biological uptake and production (remineralization plus dissolution), respectively. Eq. (2) can be used to estimate $\Gamma$ for a given time interval provided that changes in the vertical profiles of $X$ and rates of $X$ uptake and production during that time are known. In the present study, $\mathrm{Si}(\mathrm{OH})_{4}$ was used as a tracer since its rate of production (dissolution) is slow 
(assumed to be zero here) compared to its rate of advection and uptake. At the platelet ice boundaries, we assume that nutrient flux between the platelet ice and the congelation ice is negligible (no gravity drainage), and that the solute concentration at the platelet ice/seawater interface is equal to the concentration in seawater, i.e. $X(n+1)=X$ (seawater).

Although the rate of gravity drainage was assumed to be negligible, this process could influence the flux of nutrients from the congelation ice into the platelet ice and, consequently, our estimate of $\Gamma$. However, gravity drainage is most vigorous when the sea ice is young and actively growing. The sea ice we sampled in 1989 was 2 yr old and $>2 \mathrm{~m}$ thick and showed little evidence of significant growth or desalination during our study. Therefore, we believe that our assumption of negligible gravity drainage is justified.

Once $\Gamma$ was estimated from the $\mathrm{Si}(\mathrm{OH})_{4}$ data, rates of $\mathrm{PO}_{4}$ production (remineralization) were inferred from changes in $\mathrm{PO}_{4}$ profiles by rearranging Eq. (2) and solving for $P$ :

$$
P(i)=\frac{\partial \mathrm{PO}_{4}(i)}{\partial t}-\Gamma \frac{\partial^{2} \mathrm{PO}_{4}(i)}{\partial z^{2}}+U(i)
$$

where variables are as defined in Eq. (2).

\section{RESULTS}

During the austral spring of 1989, a massive bloom of microalgae dominated by the colonial pennate diatom Nitzschia stellata was observed within the platelet ice of McMurdo Sound (Fig. 2). Between October 31 and December 3, vertically integrated algal biomass increased from 9.4 to $37.4 \mathrm{~g} \mathrm{C} \mathrm{m}^{-2}$ (0.26 to $1.09 \mathrm{~g} \mathrm{chl} \mathrm{a}$

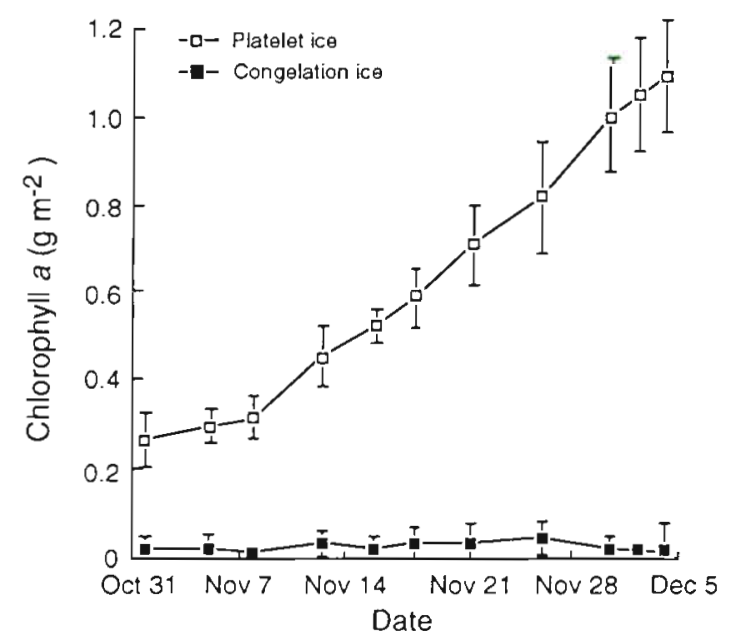

Fig. 2. Seasonal changes in vertically integrated chlorophyll a observed in the congelation and platelet ice layers of McMurdo Sound, Antarctica, in 1989. The vertical bars represent the standard deviation of the mean of 6 samples

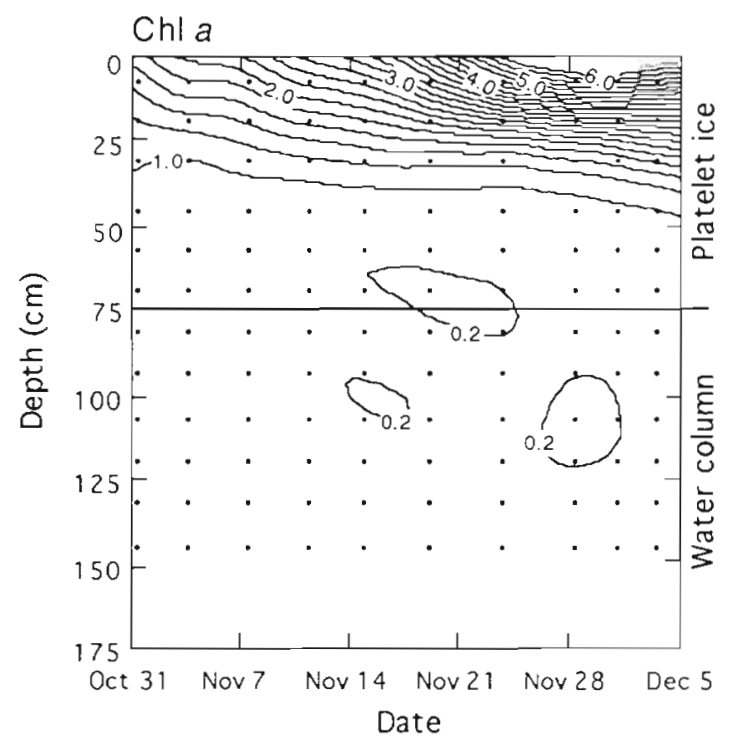

Fig. 3. Contour plot of chlorophyll a $\left(\mathrm{g} \mathrm{m}^{-3}\right)$ within the platelet layer and upper water column in McMurdo Sound, Antarctica, in 1989. The depth of the platelet ice was 0.65 to $0.75 \mathrm{~m}$

$\mathrm{m}^{-2}$ ). Distributions of algal pigments were highly stratified (Fig. 3), exhibiting an exponential decline with depth. The fraction of integrated chl a located in the upper $0.125 \mathrm{~m}$ (near the congelation ice/platelet ice interface) varied temporally from 38 to $90 \%$. Concentrations of $\mathrm{chl} a$ in this layer increased from $850 \mathrm{mg} \mathrm{m}^{-3}$ on October 31 to $6550 \mathrm{mg} \mathrm{m}^{-3}$ on December 3 . Throughout the entire sampling season, chl $\boldsymbol{a}$ in the bottom $0.05 \mathrm{~m}$ of the congelation ice remained at much lower concentrations (Fig. 2). Biomass accumulation was greatest in the upper platelet ice where light levels were highest (Arrigo et al. 1993b), reaching $>7 \mathrm{~g} \mathrm{C}$ $\mathrm{m}^{-3} \mathrm{~d}^{-1}$ between $0 \mathrm{~m}$ and $0.125 \mathrm{~m}$ depth (Fig. 4A). Most depths exhibited a temporal increase in microalgal biomass accumulation throughout the study period. When integrated vertically over the depth of the platelet ice layer, microalgal biomass accumulation exhibited a similar increase over time, from $169.8 \mathrm{mg} \mathrm{C}$ $\mathrm{m}^{-2} \mathrm{~d}^{-1}$ on October 31 to $>1200 \mathrm{mg} \mathrm{C} \mathrm{m}^{-2} \mathrm{~d}^{-1}$ on November 29 (Fig, 4B).

Ratios of C:chl a (g:g), C:N (mol:mol), C:P (mol:mol), $\mathrm{N}: \mathrm{P}$ (m:m), and Si:P (mol:mol) for sea ice algae measured $34.0 \pm 12.1(n=21), 6.8 \pm 1.0(n=21), 107.2 \pm 9.4$ $(\mathrm{n}=21), 16.0 \pm 2.5(\mathrm{n}=21)$, and $18.5 \pm 2.4(\mathrm{n}=21)$, respectively, during our study, exhibiting no identifiable temporal pattern (Fig. 5). Platelet ice microalgae maintained high internal nitrogen pools (Table 1), with internal $\mathrm{NO}_{3}$ concentrations ranging from 2.3 to 9.0 mol \% of total organic $N$, and free amino acid nitrogen varying from 11.3 to $17.8 \%$ of total protein $\mathrm{N}$.

Profiles of bacterial abundance within the interstitial waters of the platelet ice layer at Site IF were deter- 

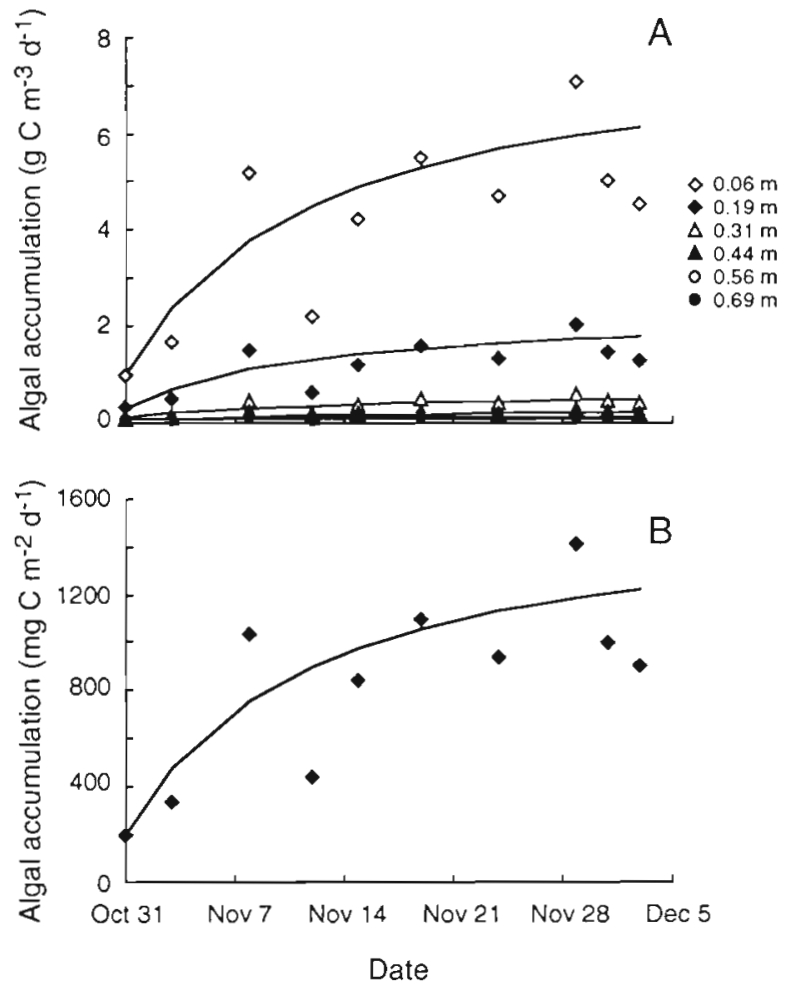

Fig. 4. Seasonal changes in the rate of microalgal biomass accumulation within the platelet ice layer $(A)$ as a function of depth and (B) depth-integrated. Line drawn by inspection to indicate temporal trend

mined for samples collected between November 15, 1989, and December 3, 1989 (Fig. 6A). Any bacteria (or heterotrophic protists) which remained attached to the platelet ice crystals during sampling were not collected. Therefore, while the following numbers most likely underestimate the actual microheterotrophic biomass within the platelet layer, they should provide insight as to their vertical distributions. Peak bacterial

Table 1. A comparison between the elemental composition of microalgae collected from the platelet ice of McMurdo Sound ( $\mathrm{n}=21)$ and values typical of light-limited marine diatoms. Int. $\mathrm{NO}_{3}-\mathrm{N}(\mathrm{mol} \% \mathrm{~N}$ ): internal nitrate pool as a percent of total organic $N_{i}$ FAA: internal free amino acid

\begin{tabular}{|c|c|c|}
\hline & $\begin{array}{l}\text { Platelet ice } \\
\text { algae }\end{array}$ & $\begin{array}{l}\text { Light limited } \\
\text { diatoms }\end{array}$ \\
\hline Int. $\mathrm{NO}_{3}-\mathrm{N}(\mathrm{mol} \% \mathrm{~N})$ & $6.2 \pm 3.3$ & $\geq 0$ \\
\hline FAA-N:protein-N $1 \%$ & $14.5 \pm 1.5$ & $\geq 2.5$ \\
\hline C:chl a $(\mathrm{g}: \mathrm{g})$ & $34.0 \pm 12.1$ & $20-60$ \\
\hline$N: \operatorname{chl} a(g: g)$ & $4.3 \pm 0.5$ & $1.9-2.4$ \\
\hline $\mathrm{C}: \mathrm{N}(\mathrm{mol}: \mathrm{mol})$ & $6.8 \pm 1.0$ & 6.6 \\
\hline C:P (mol:mol) & $107.2 \pm 9.4$ & 106 \\
\hline $\mathrm{N}: \mathrm{P}(\mathrm{mol}: \mathrm{mol})$ & $16.0 \pm 2.5$ & 16 \\
\hline Si:P (mol:mol) & $18.5 \pm 2.3$ & 17 \\
\hline C:N:Si:P (mol:mol) & $107.2: 16.0: 18.5: 1$ & $106: 16: 17: 1$ \\
\hline
\end{tabular}
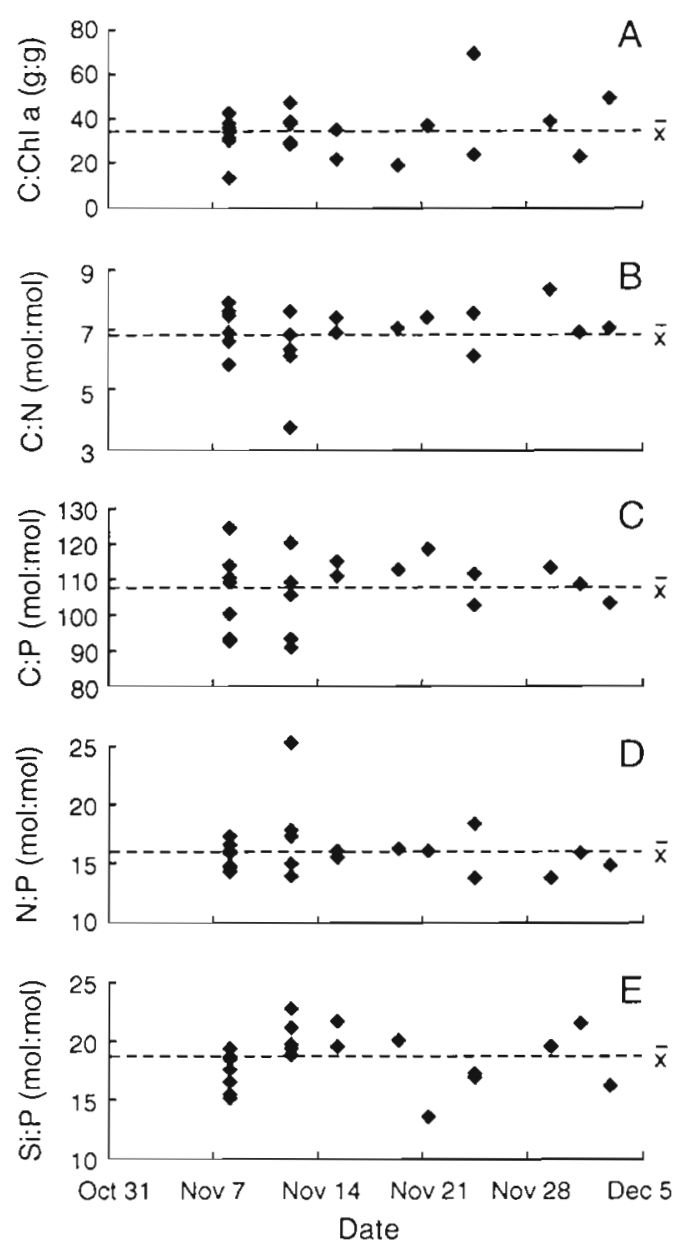

Fig. 5. Variation in biochemical ratios for sea ice microalgae collected from within the platelet layer in McMurdo Sound Antarctica, in 1989. The symbol $\bar{x}$ denotes the seasonal mean value. Multiple data for a single date represent different depths within the platelet ice

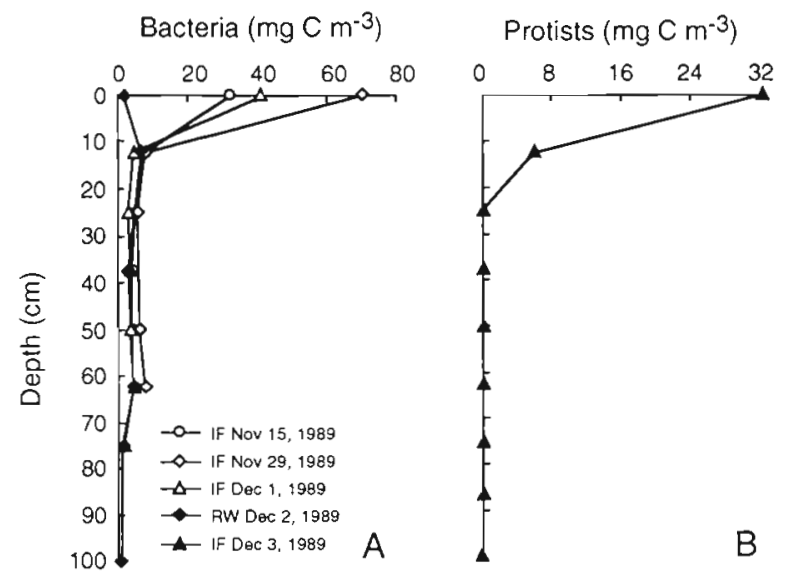

Fig. 6. Vertical profiles of (A) bacteria and (B) protists from within the platelet layer and upper water column in McMurdo Sound, Antarctica, in 1989. The depth of the platelet ice was 0.65 to $0.75 \mathrm{~m}$. IF and RW as in Fig. 1 
abundances were observed at the congelation ice/ platelet ice interface on November 29 at Site IF, where concentrations reached $68 \mathrm{mg} \mathrm{C} \mathrm{m}{ }^{-3}\left(6.3 \times 10^{11}\right.$ cells $\mathrm{m}^{-3}$ ). Bacterial numbers declined exponentially with depth throughout the platelet layer at Site IF on all dates sampled, mirroring the vertical distribution of autotrophic biomass.

The vertical distribution of protists within the interstitial waters of the platelet ice was determined from cell counts for a single profile obtained on December 3 , 1989 from Site IF (Fig. 6B). The heterotrophic protist component of the microbial community included dinoflagellates, choanoflagellates, and naked flagellates, none in particular abundance. Like autotrophic and bacterial biomass, heterotrophic protists showed an exponential decrease with depth, with a peak concentration of $32 \mathrm{mg} \mathrm{C} \mathrm{m} \mathrm{m}^{-3}$ near the congelation ice/
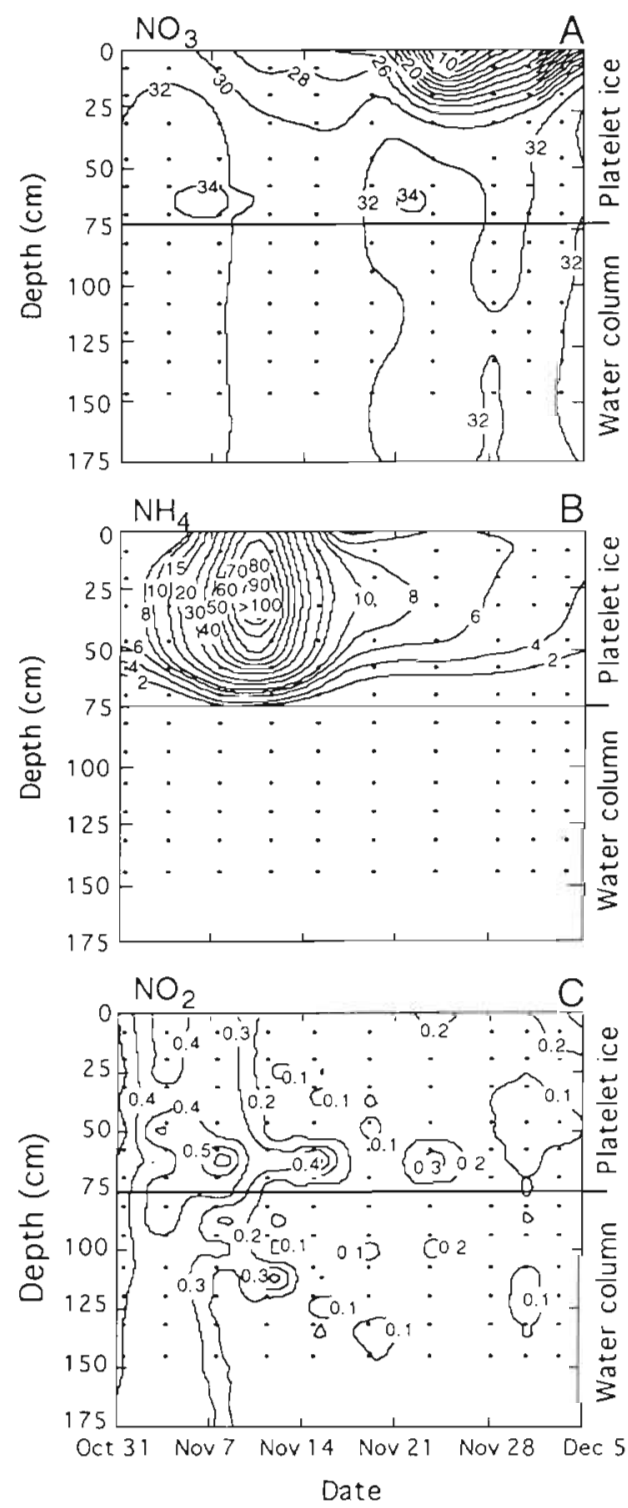

platelet ice interface. This value declined rapidly to near zero below a depth of $0.25 \mathrm{~m}$.

$\mathrm{NO}_{3}$ concentrations remained high throughout the platelet ice and upper water column at Site IF for the first half of the 1989 field season (October 31 to November 19), generally ranging from 30 to $32 \mathrm{mmol}$ $\mathrm{m}^{-3}$ (Fig $7 \mathrm{~A}$ ). After November $19, \mathrm{NO}_{3}$ concentrations were reduced to $6 \mathrm{mmol} \mathrm{m} \mathrm{m}^{-3}$ in the upper $0.3 \mathrm{~m}$ of the platelet ice, with maximum depletion coinciding with the depth and timing of the chl a maximum (Fig. 3). A secondary feature, a slight elevation in $\mathrm{NO}_{3}$ at a depth of 0.65 to $0.75 \mathrm{~m}$, can be seen in mid- to late November.

Concentrations of $\mathrm{NH}_{4}$ were far greater in the platelet ice ( 5 to $150 \mathrm{mmol} \mathrm{m}^{-3}$ ) than in the underlying water column $\left(0.5 \mathrm{mmol} \mathrm{m}^{-3}\right)$ throughout the field season (Fig. 7B), suggesting that the platelet layer was a site of considerable $\mathrm{NH}_{4}$ remineralization. In general, $\mathrm{NH}_{4}$ concentrations in the platelet ice ranged from 5 to $10 \mathrm{mmol} \mathrm{m}^{-3}$ throughout November and early December. However, a striking $\mathrm{NH}_{4}$ peak was observed in early November, with concentrations $>100 \mathrm{mmol} \mathrm{m}^{-3}$ throughout much of the platelet layer. This pulse dissi-
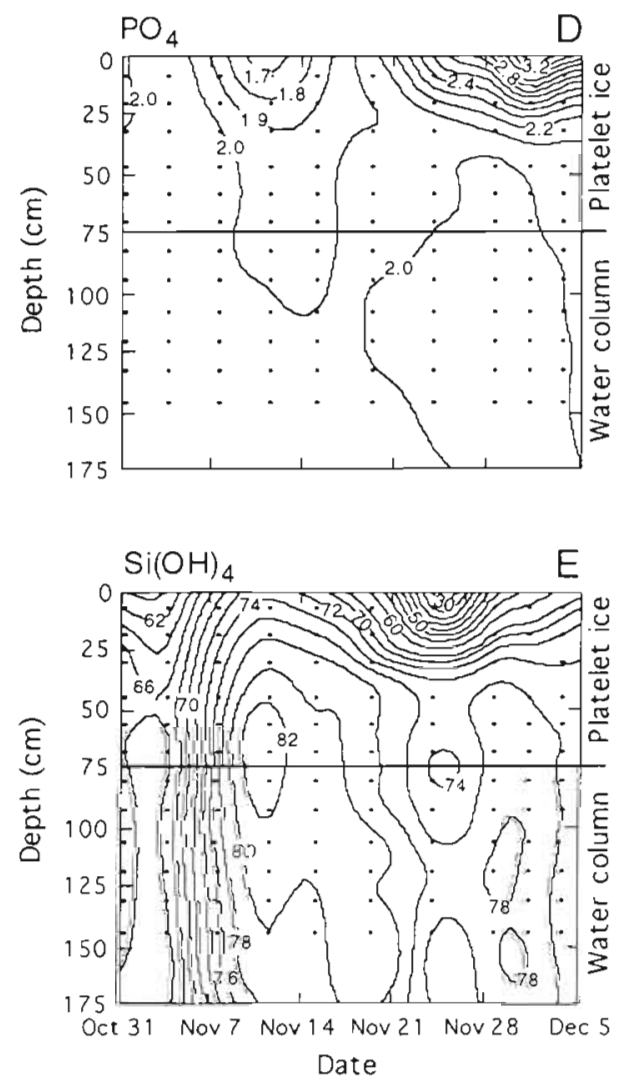

Fig. 7. Contour plots of (A) nitrate, (B) ammonıum, (C) nitrite, (D) phosphate, and (E) silicic acid concentrations ( $\mathrm{mmol} \mathrm{m} \mathrm{m}^{-3}$ ) within the platelet layer and upper water column at Site IF in McMurdo Sound, Antarctica, in 1989. The depth of the platelet ice was 0.65 to $0.75 \mathrm{~m}$ 
pated over time, and by mid-November, $\mathrm{NH}_{4}$ concentrations had declined to the previously measured concentration of 5 to $10 \mathrm{mmol} \mathrm{m}^{-3}$. Interestingly, the onset of the rapid depletion of $\mathrm{NO}_{3}$ observed in the upper platelet ice (Fig. 7A) coincided approximately with the dissipation of the $\mathrm{NH}_{4}$ pulse.

$\mathrm{NO}_{2}$ was much more uniformly distributed within the platelet ice than the other nitrogenous nutrients, ranging from $<0.1$ to $>0.6 \mathrm{mmol} \mathrm{m} \mathrm{m}^{-3}$ (Fig. 7C). The abundance of $\mathrm{NO}_{2}$ in the platelet layer in November was greatest at a depth of 0.65 to $0.75 \mathrm{~m}$, corresponding approximately to the depth of the nitrate peak (Fig. 7A).

Concentrations of $\mathrm{PO}_{4}$ remained very close to $2 \mathrm{mmol}$ $\mathrm{m}^{-3}$ in the water column and in the lower $0.3 \mathrm{~m}$ of the platelet ice for most of the sampling period (Fig. 7D). In contrast, within the upper layers of the platelet ice, where algal biomass was greatest, there was marked temporal variation in $\mathrm{PO}_{4}$ concentration. In early November, $\mathrm{PO}_{4}$ concentrations declined slightly, reaching a minimum of $<1.7 \mathrm{mmol} \mathrm{m} \mathrm{m}^{-3}$ by November 11 . Concentrations of $\mathrm{PO}_{4}$ increased thereafter to normal levels by November 18 and continued to increase until early December when concentrations reached their maximum of $3.73 \mathrm{mmol} \mathrm{m}^{-3}$.

The pattern of $\mathrm{Si}(\mathrm{OH})_{4}$ variation within the platelet ice (Fig. 7E) was similar to that exhibited by nitrate (Fig. 7A). Substantial $\mathrm{Si}(\mathrm{OH})_{4}$ depletion was observed in the upper platelet ice beginning in late November, with values as low as $16 \mathrm{mmol} \mathrm{m}^{-3}$. This depletion coincided approximately both temporally and spatially with the depletion of $\mathrm{NO}_{3}$ and with the increase in $\mathrm{PO}_{4}$. $\mathrm{Si}(\mathrm{OH})_{4}$ concentrations in the upper water column were much more variable than the other nutrients measured, varying temporally by approximately $30 \%$. Concentrations in the water column were minimal $\left(-60 \mathrm{mmol} \mathrm{m}^{-3}\right)$ in late October, increasing to a peak of $>80 \mathrm{mmol} \mathrm{m} \mathrm{m}^{-3}$ by the first week of November.

Amino acid concentrations in the platelet ice were very high and exhibited a general exponential decline with depth on December 3 at Site IF (Table 2). Glutamate was the most abundant amino acid in the upper platelet layer, reaching $207 \mu \mathrm{mol} \mathrm{m} \mathrm{m}^{-3}$. Phenylalanine $\left(160 \mu \mathrm{mol} \mathrm{m} \mathrm{m}^{-3}\right)$, asparagine $\left(141 \mu \mathrm{mol} \mathrm{m}^{-3}\right)$, arginine $\left(137 \mu \mathrm{mol} \mathrm{m} \mathrm{m}^{-3}\right)$, alanine $\left(133 \mu \mathrm{mol} \mathrm{m}{ }^{-3}\right)$, and glutamine (122 $\mu \mathrm{mol} \mathrm{m}^{-3}$ ) were also relatively abundant in this layer. Serine $\left(124 \mu \mathrm{mol} \mathrm{m}^{-3}\right)$ and glycine $\left(65 \mu \mathrm{mol} \mathrm{m} \mathrm{m}^{-3}\right)$ peaked below the surface, at a depth of 0.125 to $0.25 \mathrm{~m}$, the only amino acids to do so. Amino acid concentrations in the water column were much lower than in the platelet ice, generally below detectable limits.

Unlike amino acids, the sugars glucose, fructose and sucrose exhibited maximum concentrations at intermediate depths within the platelet ice, rather than at the congelation ice/platelet ice interface (Table 2). Peak concentrations for the 3 sugars were similar,

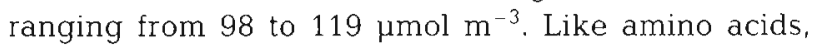
sugar concentrations in the water column were below detectable limits

Rates of seawater exchange $(\Gamma)$ calculated from Eq. (2) using $\mathrm{Si}(\mathrm{OH})_{4}$ as a tracer ranged from a minimum of $0.06 \mathrm{~m}^{-2} \mathrm{~d}^{-1}$ in late November, to a peak of $0.61 \mathrm{~m}^{-2} \mathrm{~d}^{-1}$ in late October (Fig. 8). As an independent check on the temporal variation in $\Gamma$ predicted by Eq. (2) for $\mathrm{Si}(\mathrm{OH})_{4}$, we also used $\mathrm{NO}_{3}$ as a tracer of seawater exchange (Fig. 8). This was done with the understanding that $\mathrm{NO}_{3}$ would probably be less reliable than Si $(\mathrm{OH})_{4}$, since $\mathrm{NO}_{3}$ is not as conservative, being the end product of bacterial nitrification. The resulting estimates of $\Gamma$ were approximately an order of magnitude higher than those obtained from the $\mathrm{Si}(\mathrm{OH})_{4}$ data, ranging from 0.12 to $3.66 \mathrm{~m}^{-2} \mathrm{~d}^{-1}$. Although the mag-

Table 2. Vertical profiles of simple sugar and amino acid concentrations ( $\mu \mathrm{mol} \mathrm{m} \mathrm{m}^{-3}$ ) measured within the platelet layer in McMurdo Sound, Antarctica, on December 3, 1989. Gluc: glucose; Fruc: fructose; Sucr: sucrose. Asp: aspartic acid; Glu: glutamic acid; Bga: $\beta$-glutamic acid; Asn: asparagine; Ser: serine; Gln: glutamine; Gly: glycine; Arg: arginine; Ala: alanine; Tyr: tyrosine; Met: methionine; Val: valine; Phe: phenylalanine; lle: isoleucine; Leu: leucine; Lys: lysine

\begin{tabular}{|c|c|c|c|c|c|c|c|c|c|c|c|c|c|c|c|c|c|c|c|c|c|}
\hline \multirow{2}{*}{$\begin{array}{l}\text { Depth } \\
\text { (cm) }\end{array}$} & \multicolumn{4}{|c|}{$\longrightarrow$ Sugars } & \multirow[b]{2}{*}{ Asp } & \multirow[b]{2}{*}{ Glu } & \multirow[b]{2}{*}{$\mathrm{Bga}$} & \multirow[b]{2}{*}{ Asn } & \multirow[b]{2}{*}{ Ser } & \multirow[b]{2}{*}{ Gln } & \multirow[b]{2}{*}{ Gly } & \multicolumn{3}{|c|}{ - Amino acids } & \multirow{2}{*}{ Met } & \multirow[b]{2}{*}{ Val } & \multirow[b]{2}{*}{ Phe } & \multirow[b]{2}{*}{ Ile } & \multirow[b]{2}{*}{ Leu } & \multirow[b]{2}{*}{ Lys } & \multirow[b]{2}{*}{ Total } \\
\hline & Gluc & Fruc & Sucr & Total & & & & & & & & Arg & Ala & Tyr & & & & & & & \\
\hline 6 & 20 & 25 & 0 & 44 & 66 & 207 & 12 & 141 & 44 & 122 & 42 & 137 & 133 & 0 & 0 & 0 & 160 & 0 & 0 & 0 & 1064 \\
\hline 19 & 0 & 0 & 0 & 0 & 54 & 48 & 0 & 0 & 124 & 29 & 65 & 32 & 59 & 0 & 0 & 0 & 66 & 0 & 0 & 0 & 477 \\
\hline 31 & 55 & 30 & 119 & 204 & 22 & 43 & 0 & 0 & 31 & 29 & 11 & 18 & 0 & 0 & 0 & 0 & 59 & 0 & 0 & 0 & 213 \\
\hline 44 & 98 & 106 & 0 & 205 & 19 & 29 & 0 & 0 & 24 & 20 & 8 & 16 & 26 & 0 & 0 & 0 & 69 & 0 & 0 & 0 & 211 \\
\hline 56 & 27 & 20 & 0 & 47 & 13 & 15 & 0 & 0 & 12 & 12 & 0 & 15 & 46 & 0 & 0 & 0 & 71 & 0 & 0 & 0 & 184 \\
\hline 69 & 21 & 43 & 0 & 65 & 18 & 36 & 0 & 0 & 18 & 22 & 2 & 18 & 28 & 0 & 0 & 0 & 37 & 0 & 0 & 0 & 179 \\
\hline 81 & 0 & 0 & 0 & 0 & 10 & 6 & 0 & 0 & 11 & 0 & 0 & 9 & 47 & 0 & 0 & 0 & 17 & 0 & 0 & 0 & 100 \\
\hline 94 & 0 & 0 & 0 & 0 & 0 & 0 & 0 & 0 & 0 & 0 & 0 & 0 & 0 & 0 & 0 & 0 & 0 & 0 & 0 & 0 & 0 \\
\hline 106 & 0 & 0 & 0 & 0 & 0 & 0 & 0 & 0 & 0 & 0 & 0 & 0 & 0 & 0 & 0 & 0 & 0 & 0 & 0 & 0 & 0 \\
\hline 119 & 0 & 0 & 0 & 0 & 0 & 0 & 0 & 0 & 0 & 0 & 0 & 0 & 0 & 0 & 0 & 0 & 0 & 0 & 0 & 0 & 0 \\
\hline 131 & 0 & 0 & 0 & 0 & 0 & 0 & 0 & 0 & 0 & 0 & 0 & 0 & 0 & 0 & 0 & 0 & 0 & 0 & 0 & 0 & 0 \\
\hline 144 & 0 & 0 & 0 & 0 & 0 & 0 & 0 & 0 & 0 & 0 & 0 & 0 & 0 & 0 & 0 & 0 & 0 & 0 & 0 & 0 & 0 \\
\hline
\end{tabular}




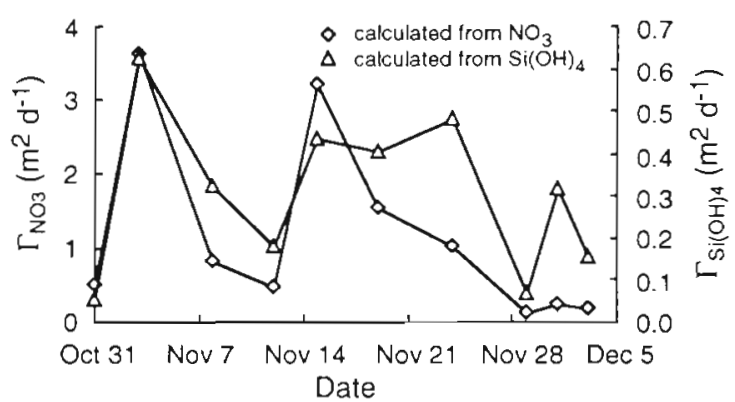

Fig. 8. Variation in seawater exchange rate $\left(\Gamma, \mathrm{m}^{2} \mathrm{~d}^{-1}\right)$ within the platelet layer in McMurdo Sound, Antarctica, in 1989 computed from Eq. (1) using nitrate and silicic acid as tracers

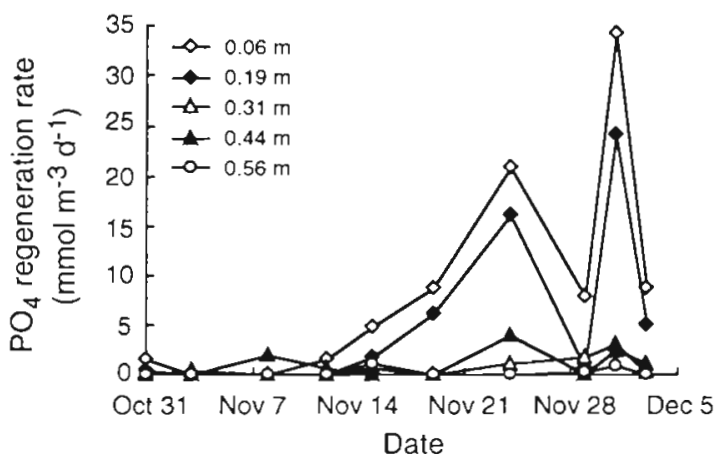

Fig. 9. Seasonal changes in phosphate regeneration rate at 5 depths within the platelet layer at Site IF in McMurdo Sound, Antarctica, in 1989 (computed from Eq. 2)

nitudes were different using the 2 methods, the temporal pattern of $\Gamma$ was similar. Throughout the duration of the study, $\Gamma$ appeared to vary with a $14 \mathrm{~d}$ frequency similar to that displayed by tidal amplitude (Cota \& Sullivan 1990), presumably due to changes in current velocity and pressure within the platelet layer associated with variation in tidal range.

Remineralization of $\mathrm{PO}_{4}$ calculated from Eq. (3) was highly dependent on date and depth within the platelet layer (Fig, 9), $\mathrm{PO}_{4}$ remineralization was greatest within the upper $0.12 \mathrm{~m}$ of the platelet ice where

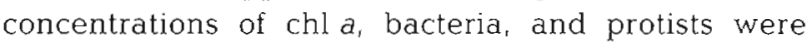
greatest. More than $95 \%$ of all regenerated $\mathrm{PO}_{4}$ was produced in the upper $0.25 \mathrm{~m}$. Rates of $\mathrm{PO}_{4}$ remineralization increased exponentially between early and late spring, attaining rates as high as $35 \mathrm{mmol} \mathrm{P} \mathrm{m}^{-3} \mathrm{~d}^{-1}$ in the upper platelet ice.

On December 2, chl a and nutrient concentrations were determined for the congelation ice $(0.2 \mathrm{~m}$ resolution) and the platelet layer at Site RW. This allowed us to determine the differences in nutrient concentration and microbial standing stock between a high (IF) and low (RW) biological activity site (summarized in Table 3). Concentrations of chl a were low in the congelation and platelet ice at RW (Fig 10F), rarely ex- ceeding $1 \mathrm{mg}$ chl $\mathrm{a} \mathrm{m}^{-3}$. Unlike at Site IF, maximum chl a concentrations at Site RW were observed within the congelation ice interior. Microalgal biomass in the

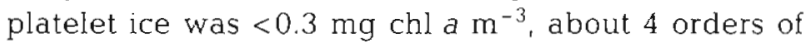
magnitude less than peak concentrations at Site IF (Fig. 10A). The congelation ice at both sites contained bands of enhanced chl a concentration at 1.0 to $1.5 \mathrm{~m}$ depth. Site RW had an additional pigment band at a depth of $3.0 \mathrm{~m}$. Unlike Site IF, the bacterial profile exhibited little vertical structure on December 2 at Site RW, varying between $0.89 \mathrm{mg} \mathrm{C} \mathrm{m}^{-3}\left(8.2 \times 10^{9}\right.$ cells $\left.\mathrm{m}^{-3}\right)$ and $6.9 \mathrm{mg} \mathrm{C} \mathrm{m}^{-3}\left(6.4 \times 10^{10}\right.$ cells $\left.\mathrm{m}^{-3}\right)$. Maximum bacterial cell numbers and biomass at Site RW were an order of magnitude lower than those measured at Site IF.

$\mathrm{NO}_{3}$ concentrations in the platelet ice and upper water column at both Site IF (Fig. 10B) and Site RW (Fig. 10G) were generally similar, about $32 \mathrm{mmol} \mathrm{m}^{-3}$, and approximately an order of magnitude higher than in the congelation ice. A notable exception can be seen in the upper platelet ice where $\mathrm{NO}_{3}$ concentration was reduced to $18.8 \mathrm{mmol} \mathrm{m}^{-3}$ at Site IF. Site IF exhibited higher $\mathrm{NO}_{3}$ concentrations in the congelation ice $(4.4 \pm$ $\left.1.4 \mathrm{mmol} \mathrm{\textrm {m } ^ { - 3 }}\right)$ than at Site RW $\left(3.2 \pm 2.0 \mathrm{mmol} \mathrm{m}^{-3}\right)$, both exhibiting little vertical structure.

$\mathrm{NH}_{4}$ exhibited a great deal of vertical variation at both Site IF (Fig. 10C) and Site RW (Fig. 10H). Peak concentrations in the congelation ice were similar (4.1 $\mathrm{mmol} \mathrm{m}^{-3}$ at Site IF; $4.2 \mathrm{mmol} \mathrm{m}^{-3}$ at Site RW), and coincided with the depth of the chl a peaks. Concentrations of $\mathrm{NH}_{4}$ in the congelation ice ranged from 0.6 to $4.1 \mathrm{mmol} \mathrm{m}^{-3}$ at Site IF and from 0.6 to $4.2 \mathrm{mmol} \mathrm{m}^{-3}$ at Site RW. In the platelet layer, concentrations of $\mathrm{NH}_{4}$ were approximately 2 -fold greater at Site IF than at Site RW, with mean levels of $5.9 \pm 0.9 \mathrm{mmol} \mathrm{m}^{-3}$ and $2.3 \pm 0.6 \mathrm{mmol} \mathrm{m} \mathrm{m}^{-3}$, respectively, and peak values of $6.9 \mathrm{mmol} \mathrm{m}^{-3}$ and $3.2 \mathrm{mmol} \mathrm{m}^{-3}$, respectively. Levels of $\mathrm{NH}_{4}$ in the upper water column were also higher at

Table 3. Comparison of high biomass Site IF with low biomass Site RW

IF (1 Dec 1989) RW (2 Dec 1989)

$\begin{array}{lcc}\text { Congelation ice } & \\ \text { Peak chl a }\left(\mathrm{mg} \mathrm{m}^{-3}\right) & >1000 & <1 \\ \mathrm{NO}_{3}(\mathrm{mmol} \mathrm{m})^{-3} & 4.4 \pm 1.4 & 3.2 \pm 2.0 \\ \left.\mathrm{NH}_{4}(\mathrm{mmol} \mathrm{m})^{-3}\right) & 0.6-4.1 & 0.6-4.2 \\ \left.\mathrm{PO}_{4}(\mathrm{mmol} \mathrm{m})^{-3}\right) & 0.43 \pm 0.68 & 0.12 \pm 0.11 \\ \mathrm{Si}(\mathrm{OH})_{4}\left(\mathrm{mmol} \mathrm{m}^{-3}\right) & 5.66 \pm 2.47 & 3.44 \pm 2.44 \\ & & \\ \text { Platelet ice } & & <1 \\ {\mathrm{Peak} \mathrm{chl} \mathrm{a}\left(\mathrm{mg} \mathrm{m}^{-3}\right)}_{\left.\mathrm{NO}_{3}(\mathrm{mmol} \mathrm{m})^{-3}\right)} & 19-32 & 32 \\ \left.\mathrm{NH}_{4}(\mathrm{mmol} \mathrm{m})^{-3}\right) & 5.9 \pm 0.9 & 2.3 \pm 0.6 \\ \mathrm{PO}_{4}(\mathrm{mmol} \mathrm{m})^{-3} & 1.90-3.73 & 1.98 \pm 0.05 \\ \mathrm{SiOH}_{4}\left(\mathrm{mmol} \mathrm{m}^{3}\right) & 61.2-78.6 & 74.9 \pm 1.1\end{array}$


Fig. 10. Vertical profiles of $(A, F)$ chlorophyll $a_{1}(B, G)$ nitrate, $(C$, H) ammonium, (D, I) phosphate, and $(E, J)$ silicic acid in the congelation ice, platelet ice and upper water column at Sites IF (1 December) and RW (2 December in McMurdo Sound, Antarctica, in 1989
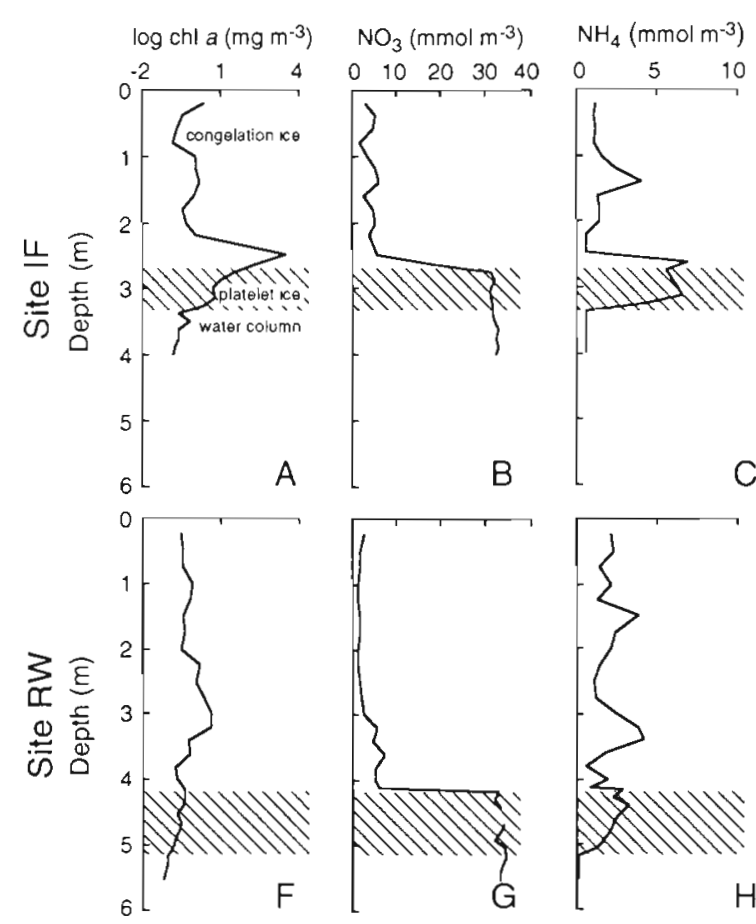
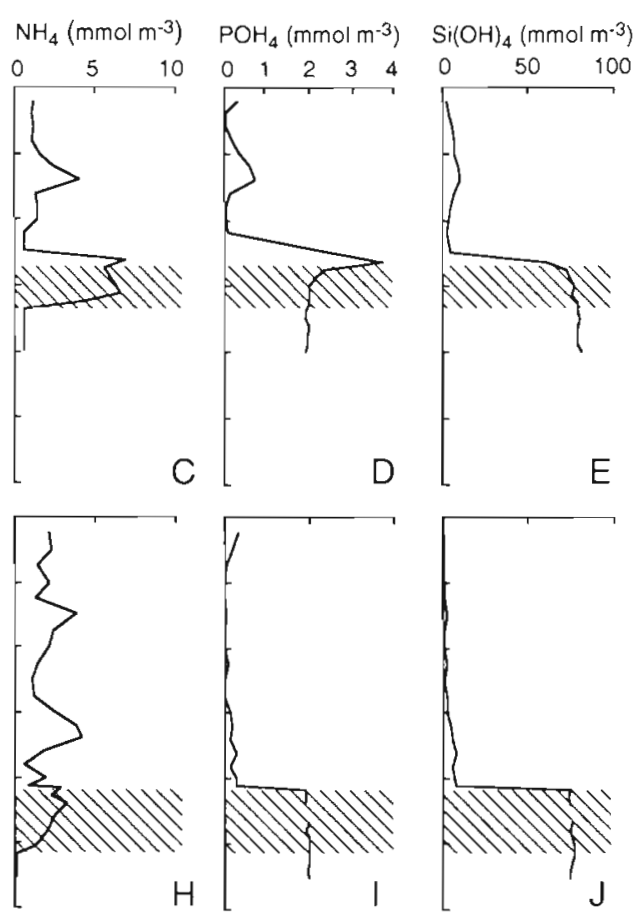

Site IF $\left(0.64 \pm 0.0 \mathrm{mmol} \mathrm{m}^{-3}\right)$ than at Site RW $(0.14 \pm$ $0.02 \mathrm{mmol} \mathrm{m}^{-3}$ ).

$\mathrm{PO}_{4}$ exhibited more vertical variation at Site IF (Fig. 10D) than at Site RW (Fig. 10I). Concentrations of $\mathrm{PO}_{4}$ in the congelation ice averaged $0.43 \pm 0.68 \mathrm{mmol}$

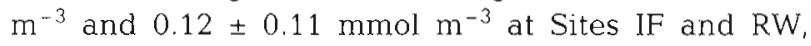
respectively. A distinct peak in $\mathrm{PO}_{4}$ concentration for the congelation ice $\left(0.58 \mathrm{mmol} \mathrm{m}^{-3}\right)$ can be seen in the profile from Site IF but not from Site RW. As with $\mathrm{NH}_{4}$, this peak coincided with the internal chl a band at $1.5 \mathrm{~m} . \mathrm{PO}_{4}$ concentration in the platelet ice and upper water column at Site RW was uniform with depth, averaging $1.98 \pm 0.05 \mathrm{mmol} \mathrm{m} \mathrm{m}^{-3}$. In contrast, $\mathrm{PO}_{4}$ exhibited a sharp peak of $3.73 \mathrm{mmol} \mathrm{m}^{-3}$ in the upper platelet ice which declined exponentially with depth. Concentrations of $\mathrm{PO}_{4}$ in the water column at Site IF were not significantly different from values at Site RW, averaging $1.95 \pm 0.04 \mathrm{mmol} \mathrm{m}^{-3}$.

Concentrations of $\mathrm{Si}(\mathrm{OH})_{4}$ in the congelation ice were higher at Site IF $\left(5.66 \pm 2.47 \mathrm{mmol} \mathrm{m}{ }^{-3}\right)$ (Fig. 10E) than at Site RW $\left(3.44 \pm 2.44 \mathrm{mmol} \mathrm{m}^{-3}\right)$ (Fig. 10J), the higher values being generally attributable to a nutrient peak at the depth of the chl a band. Like $\mathrm{PO}_{4}$, the $\mathrm{Si}(\mathrm{OH})_{4}$ concentration in the platelet ice and upper water column at Site RW was relatively constant with depth, averaging $74.9 \pm 1.1 \mathrm{mmol} \mathrm{m}^{-3}$. This was not the case at Site IF where $\mathrm{Si}(\mathrm{OH})_{4}$ was reduced by $25 \%$, to $61.2 \mathrm{mmol} \mathrm{m} \mathrm{m}^{-3}$, in the upper platelet ice. Concentrations of $\mathrm{Si}(\mathrm{OH})_{4}$ increased with depth, averaging $78.6 \pm$ 1.6 for the lower platelet ice and upper water column.

\section{DISCUSSION}

The maximum algal biomass observed in the platelet layer in McMurdo Sound during the spring of 1989 was approximately 5 times greater than the peak standing crops reported previously for any Antarctic (Palmisano \& Sullivan 1983) or Arctic (Smith et al. 1988, Welch \& Bergmann 1989) sea ice ecosystem. An analysis of the available literature indicates that seasonal peaks in chl a concentrations in Antarctic and Arctic sea ice typ-

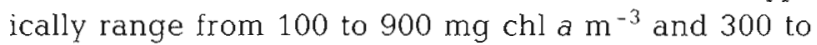
$1000 \mathrm{mg}$ chl a $\mathrm{m}^{-3}$, respectively. Although $6550 \mathrm{mg}$ chl a $\mathrm{m}^{-3}$ is among the highest reported in situ chl a concentrations for sea ice that we know of, it is similar

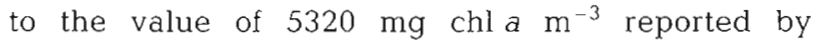
Hoshiai (1981) for a relatively thin $(0.02 \mathrm{~m})$ bottom-ice photoautotrophic community near Syowa Station, and $10100 \mathrm{mg}$ chl a $\mathrm{m}^{-3}$ observed by Lizotte \& Sullivan (1992) in the $0.01 \mathrm{~m}$ thick skeletal layer of McMurdo Sound.

The depth-dependent patterns of microalgal biomass accumulation are consistent with vertical profiles of light saturated photosynthetic rate (Arrigo et al. 1993b), which show that photosynthetic activity was greatest at the congelation ice/platelet ice interface. Depth integrated rates of microalgal biomass accumulation were maximal after mid-November when solar elevation and photoperiod were greatest. Peak accumulation rates exceeded $1 \mathrm{~g} \mathrm{C} \mathrm{m}^{-2} \mathrm{~d}^{-1}$ (Fig. 4B) and therefore are comparable to some of the more produc- 
tive oceans of the world. The accumulation of $28.1 \mathrm{~g} \mathrm{C}$ $\mathrm{m}^{-2}$ observed during the $38 \mathrm{~d}$ study is consistent with previous annual production estimates for McMurdo Sound of $41 \mathrm{~g} \mathrm{C} \mathrm{m}^{-2}$ based on short-term in situ $\mathrm{H}^{14} \mathrm{CO}_{3}{ }^{-}$uptake (Grossi et al. 1987). This production rate also exceeds the estimated $16 \mathrm{~g} \mathrm{C} \mathrm{m}^{-2}$ contributed seasonally by blooms of Phaeocystis pouchetii in the water column beneath the sea ice of McMurdo Sound (Palmisano et al. 1986).

Because platelet ice is a semi-porous structure with the potential for nutrient exchange, there has been speculation as to whether growth of algae in this system is limited by light or nutrient availability (e.g Palmisano \& Sullivan 1985). Although we performed no kinetic analyses, previous studies suggest that sea ice microalgae are similar to coastal phytoplankton in their ability to take up most macronutrients (Harrison et al. 1990, G. F Cota, J. C. Priscu \& C. W. Sullivan unpubl.). One possible exception is silicic acid, for which both Antarctic phytoplankton (Jacques 1983, Sommer 1986) and sea ice algae (Cota et al. unpubl.) appear to share a low affinity $\left(K_{\mathrm{s}}\right.$ as high as $\left.60 \mu \mathrm{M}\right)$. A comparison of observed macronutrient concentrations with typical kinetic constants for nutrient uptake indicates, however, that the growth rate of platelet ice microalgae was never nutrient limited during the course of our study. Even when maximally depleted, $\mathrm{NO}_{3}, \mathrm{NH}_{4}, \mathrm{PO}_{4}$, and $\mathrm{Si}(\mathrm{OH})_{4}$ remained high (Fig. 7)

Biochemical evidence also supports the conclusion that the platelet ice is a light limited system. Elemental ratios determined for the sea ice assemblage collected from Site IF were well within the ranges expected from nutrient sufficient cells (Table 1). This was true even for $\mathrm{Si}$, despite the apparent low affinity for $\mathrm{Si}(\mathrm{OH})_{4}$ exhibited by sea ice algae. Internal pools of free amino acids and $\mathrm{NO}_{3}$ were also much higher than would be expected for nutrient deficient cells. Studies of Arctic ice algae indicate that they also are limited by light for most of the growth season (Harrison et al. 1990), although some evidence suggests that $\mathrm{Si}(\mathrm{OH})_{4}$ may become limiting late in the bloom (Welch \& Bergman 1989, Gosselin et al. 1990). The absence of nutrient limitation in Antarctic platelet ice, given the large concentrations of chl a observed in 1989, attests to the fact that an efficient mechanism for nutrient exchange must exist within the platelet ice layer

The nutrient transport coefficients estimated here for the platelet layer ( 0.06 to $\left.0.61 \mathrm{~m}^{2} \mathrm{~d}^{-1}\right)$ are considerably lower than the range of 10 to $90 \mathrm{~m}^{2} \mathrm{~d}^{-1}$ which were reported within the mixed layer of ice covered waters in the Arctic (Cota \& Horne 1989) and Antarctic (Cota \& Sullivan 1990). However, they are approximately 3 orders of magnitude higher than typical molecular diffusion coefficients, which range from $10^{-5}$ to $10^{-4} \mathrm{~m}^{2}$ $\mathrm{d}^{-1}$. Based upon the rates of material transport esti- mated above, complete turnover of the interstitial waters within the $0.6 \mathrm{~m}$ platelet ice layer observed in McMurdo Sound in 1989 should occur on the order of

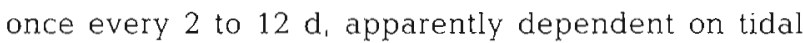
cycle. The flux of seawater (and associated dissolved constituents) into the platelet layer is likely to be facilitated by pressure gradients, which are created when seawater flowing directly beneath the ice sheet contacts structural irregularities at the lower platelet ice boundary (Darcy flow) and also by convective processes, which are driven by brine rejection at the platelet ice/congelation ice interface (Lake \& Lewis 1970, Niedrauer \& Martin 1979). However, brine rejection probably played a minor role, if any, in nutrient exchange within the platelet ice layer in 1989 since this process requires an actively growing ice sheet and the 2 yr old congelation ice exhibited little growth or desalination during our study. On the other hand, Darcy flow, which is based on the Bernoulli principle (Schlichting 1979), is important wherever structural irregularities at the surface of a porous medium (i.e. small mounds on the surface of a sand flat, ice platelets protruding from the lower platelet ice boundary) interact with an adjacent flow field. While we believe that Darcy flow is primarily responsible for replenishing the platelet ice layer with fresh nutrients, additional field experiments are necessary to test this hypothesis.

Current speeds near the surface of McMurdo Sound, which would control the rate of Darcy flow, generally range from 0.02 to $0.20 \mathrm{~m} \mathrm{~s}^{-1}$ (Barry \& Dayton 1988) and exhibit a strong diel signal apparently related to tidal height (Heath 1977, Barry \& Dayton 1988). There is also a strong fortnightly tidal signal (with a $13.7 \mathrm{~d}$ period) which is related to the subtidal frequency of planetary motion (Barry \& Dayton 1988). Tidal rectification (MacAyeal 1984, 1985) and tidally induced flexing of the Ross ice shelf (Holdsworth 1977. MacAyeal 1984) may accentuate or damp current velocities and may also influence flow within the platelet layer. Based upon temporal changes in the rates of material transport reported here, motion on this longer time scale appears to be the primary factor controlling changes in the magnitude of $\Gamma$ within the platelet ice layer. This may be misleading, however, because temporal changes in $\Gamma$ at time scales less than a few days in length were not investigated. It is conceivable, and perhaps likely, that diel variations in the tidally induced current fields (Gilmour et al. 1960, Gilmour et al. 1962, Heath 1977, Lewis \& Perkin 1985) may result in large changes in $\Gamma$ throughout the day which were not measured in this study. If so, considering the potential for large daily fluctuations in $\Gamma$, it is surprising that the apparent fortnightly pattern to the variation in $\Gamma$ was observed at all Most likely, however, the effect of diel changes in tidal amplitude on estimates of $\Gamma$ are 
spread over the whole day. That is, if silicic acid is replenished once a day, its effect will be apparent in the silicic acid uptake profiles (determined from biomass accumulation) used to compute $\Gamma$ regardless of the precise timing of the tides or of sampling.

Regardless, these results suggest that tidally mediated Darcy flow within the platelet layer was an effective mechanism for resupplying the resident microbial community with nutrients. The turnover time for the interstitial waters within the platelet layer ( 2 to $12 \mathrm{~d}$ ) estimated from $\Gamma$ was similar to the generation time of 3 to $7 \mathrm{~d}$ reported for sea ice microalgae at $-1.85^{\circ} \mathrm{C}$ in McMurdo Sound (Grossi et al. 1984, Sullivan et al. 1985). This implies that when current velocity is low, photoautotrophic growth within sea ice will be controlled by nutrient availability. Simulations of sea ice microalgal growth using a detailed ecological model (Arrigo et al. 1993a) support this hypothesis. For instance, in simulations where $\Gamma$ was set to $0.20 \mathrm{~m}^{2} \mathrm{~d}^{-1}$, nutrients were maintained at growth-saturating concentrations within the platelet layer throughout the simulation, and the photoautotrophic assemblage was light-limited. Under these conditions, microalgal growth rates were uncoupled from nutrient transport rates (i.e. turnover time was approximately a factor of 2 greater than the highest estimate of algal generation time) despite the accumulation of large amounts of algal biomass. However, in simulations where $\Gamma$ was reduced to $0.02 \mathrm{~m}^{2} \mathrm{~d}^{-1}$, the supply of nutrients was inadequate to meet algal demand and the assemblage became nutrient limited in the upper platelet ice where the bulk of the algal biomass was located. If similar transport processes control the growth of platelet ice microalgae in the field, maximum ice algal growth and accumulation rates would be predicted to occur in areas where surface current speeds, and thus nutrient transport rates, are most rapid.

Like many other microbial systems, autotrophic processes appeared to exert primary control over nutrient dynamics within the platelet ice, via the uptake of inorganic macronutrients and subsequent exudation of DOM. High rates of nutrient exchange with the underlying water column, facilitated by Darcy flow and possibly augmented by brine rejection, allowed the autotrophic community to reach extremely high standing crops in 1989. Initially, $\mathrm{NO}_{3}, \mathrm{NO}_{2}, \mathrm{PO}_{4}$, and $\mathrm{Si}(\mathrm{OH})_{4}$ were utilized for algal growth, and later, as regenerated sources of nitrogen became available, $\mathrm{NH}_{4}$ also was used. The development and maintenance of this high autotrophic biomass was the critical feature defining the interactions between the other trophic levels and nutrient pools present within the platelet ice. A noteworthy feature of the platelet ice habitat was the presence of a large amount of particulate material with little associated detritus. Considered together with the elemental composition of the particulate material which remained near the Redfield ratios, this suggests that the microbial community was not deteriorating during the time of our investigation. In contrast, the nutrient data, particularly $\mathrm{NH}_{4}$ and $\mathrm{PO}_{4}$, suggest that the platelet ice habitat was highly regenerative. The presence of a small amount of detritus observed in conjunction with elevated $\mathrm{NH}_{4}$ and $\mathrm{PO}_{4}$ concentrations is highly unusual and cannot be explained at this time.

In many marine systems, photosynthetically fixed carbon and nitrogen are released extracellularly by phytoplankton and utilized as an energy source by microheterotrophs (Fuhrman et al. 1980, Larsson \& Hagström 1982, Lignell 1990). During our study, both carbon-rich (simple sugars) and nitrogen-rich (amino acids) organic molecules were found at relatively high concentrations in the platelet ice and were associated with regions of high algal biomass; concentrations of these compounds were below the limit of detection in the water column. Algal exudation experiments carried out in McMurdo Sound in 1989 revealed that these compounds were produced and subsequently released by healthy sea ice microalgae (J. Welborn pers. comm.). It is likely that these and other more complex organic molecules were a rich source of both nitrogen and carbon for bacterial, and perhaps to a lesser extent, heterotrophic protist growth. Additional DOM was probably also derived from slower growing microalgae in lower layers of the platelet ice. As light became limiting and growth was confined to a progressively thinner layer in the uppermost levels of platelet ice, cells at greater depths became shaded (Arrigo et al. 1993b). Although exudation rates by these algae were not measured, it is well known that when light-stressed, algae produce DOM at much faster rates than do cells growing in light replete environments (Williams 1990, Wood \& Van Valen 1990).

Considering the high concentrations of amino acids measured in the platelet ice, it is reasonable to assume that pools of organic nitrogenous compounds released by algae were the source of a portion of regenerated $\mathrm{NH}_{4}$. In contrast to other macronutrients, concentrations of $\mathrm{NH}_{4}$ within the platelet ice at Site IF were consistently an order of magnitude higher than those in the water column. To maintain these high $\mathrm{NH}_{4}$ concentrations, a rich source of $\mathrm{NH}_{4}$ must have been present in the platelet ice throughout the study period, a source capable of overcoming the losses due to biological uptake and to vertical mixing, which would tend to dilute $\mathrm{NH}_{4}$ concentrations in the platelet ice layer. Preliminary experiments performed in McMurdo Sound in 1989 have shown that microheterotrophs (either bacteria or protists) present within the platelet ice were capable of remineralizing $>1.3 \mathrm{mmol} \mathrm{NH}_{4} \mathrm{~m}^{-3} \mathrm{~h}^{-1}$ (Dieckmann \& Robinson unpubl.), suggesting that 
microbial processes were primarily responsible for the high background concentrations of $\mathrm{NH}_{4}(5$ to $10 \mathrm{mmol}$ $\mathrm{m}^{-3}$ ). Rates of $\mathrm{PO}_{4}$ remineralization estimated here were also very high, approaching $35 \mathrm{mmol} \mathrm{m}^{-3} \mathrm{~d}^{-1}$ by early December in the upper layers of the platelet ice where the bulk of the microbial biomass was located. Whether remineralization was due to bacterial or eukaryotic protist metabolism is not clear, since both groups are known to take up DOM directly from seawater and excrete $\mathrm{PO}_{4}$ and $\mathrm{NH}_{4}$. However, because bacteria as a group remove as many nutrients as they produce, and protists frequently ingest bacteria (and pico- and nanoplankton) (Johannes 1965), protists were probably the primary source of remineralized nutrients in the platelet layer, as has been suggested previously for the water column (Azam et al. 1983).

Despite their apparently low numbers in the interstitial waters of the platelet ice, the abundance of bacteria and protists within the platelet layer was probably much higher than direct cell counts indicated. For instance, our chl a data showed that up to $80 \%$ of total autotrophic biomass within the platelet ice layer remained attached to ice crystal surfaces and was not collected during ADONIS sampling (Dieckmann et al. 1992). Furthermore, in a similar study conducted in the Weddell Sea, direct cell counts showed that bacteria were present at much higher concentrations on platelet ice crystal surfaces $\left(1.5\right.$ to $2.0 \times 10^{10}$ cells $\left.1^{-1}\right)$ than in the interstitial waters (S. Grossman pers. comm.). These results suggest that heterotrophic biomass in the platelet ice may have been a factor of 5 greater than the ADONIS samples indicated, and consequently, may have been sufficient to sustain $\mathrm{NH}_{4}$ concentrations of 5 to $10 \mathrm{mmol} \mathrm{m}^{-3}$.

By contrast, we also observed high $\mathrm{NH}_{4}$ concentrations in the congelation ice associated with internal pigment bands (at Sites IF and RW) and in the platelet ice layer beneath an ice sheet with virtually no autotrophic activity (at Site RW). It is unlikely that the sole source of this $\mathrm{NH}_{4}$ was the degrading algal population within the congelation ice, particularly at Site RW, since the potential $\mathrm{NH}_{4}$ source was almost certainly insufficient to overcome dilution which would have occurred during seawater exchange. Previous studies (Biggs et al. 1985) have shown that high $\mathrm{NH}_{4}$ concentrations are often found beneath the pack ice of the western Ross Sea and in waters melted from the Ross Ice Shelf. Whether this represents $\mathrm{NH}_{4}$ produced by biological degradation of organic material or $\mathrm{NH}_{4}$ sequestration by some physical process is not clear.

$\mathrm{NH}_{4}$ concentrations within the platelet ice reached a peak of $\sim 150 \mathrm{mmol} \mathrm{m}^{-3}$ in early November (Fig. 7B), approximately 300 -fold greater than water column levels. The source of this large pulse of $\mathrm{NH}_{4}$ is unknown; it is doubtful that concentrations could have reached this level through microheterotrophic processes alone. One possible source is through excretion by macroheterotrophs such as copepods or krill, which are known to graze on the surfaces of ice crystals (Smetacek et al. 1992). A single macrozooplankton grazing and excretion event may have taken place in early November, after which the $\mathrm{NH}_{4}$ was flushed out of the platelet ice system over a period of several days. However, large macrozooplankton were not observed in association with the platelet ice during our study or in the study by Smetacek et al. (1992) in the Weddell Sea. In addition, the $\mathrm{NH}_{4}$ peak in early November was not accompanied by a concomitant increase in $\mathrm{PO}_{4}$ which would be anticipated if macrozooplankton grazing were the source of $\mathrm{NH}_{4}$.

Interestingly, an $\mathrm{NH}_{4}$ source external to the platelet ice community (i.e. if macrozooplankton fed elsewhere and released $\mathrm{NH}_{4}$ into the platelet ice layer) could help explain the relatively high transport rates calculated from $\mathrm{NO}_{3}$ concentrations. This is because some of the increase in algal nitrogen would have been supported by this 'new' $\mathrm{NH}_{4}$ source, resulting in an overestimate of both $\mathrm{NO}_{3}$ uptake and $\Gamma$ (in Eq. 2). If macrozooplankton were the source of elevated $\mathrm{NH}_{4}$ in the platelet layer, episodic $\mathrm{NH}_{4}$ regeneration by these organisms may play an important role in the nutrient dynamics of the sea ice ecosystem, particularly at those times when seawater exchange diminishes and nitrogen becomes limiting. This is evidenced by $\mathrm{NO}_{3}$ in the upper platelet ice (Fig. 7A) which became depleted only after the $\mathrm{NH}_{4}$ pulse had dissipated.

The presence of $\mathrm{NO}_{2}$ at concentrations of 0.1 to $0.6 \mathrm{mmol} \mathrm{m}^{-3}$ indicates that nitrifying bacteria may have been present in the platelet ice and were converting some of the accumulated $\mathrm{NH}_{4}$ to $\mathrm{NO}_{3}$, with $\mathrm{NO}_{2}$ being produced as an intermediate. Clearly, platelet ice appears to be an ideal habitat for nitrifying bacteria. Nitrifiers are inhibited by high light (Müller-Nuglück \& Engel 1961, Bock 1965), and therefore, most nitrification in the water column occurs near the base of the photic zone (Ward et al. 1982). This is consistent with our observation of coincident $\mathrm{NO}_{2}$ and $\mathrm{NO}_{3}$ peaks in the lower platelet ice where light levels were substantially reduced (Arrigo et al. 1993b), implying that nitrification rates were greatest there. Nitrification in the water column is coupled to primary production in overlying waters because this production is the ultimate source of the regenerated substrates used for nitrification. Consistent with this view, large amounts of nitrogen-rich organics were produced in the upper platelet ice in 1989 and were subsequently converted to $\mathrm{NH}_{4}$. The high concentrations of $\mathrm{NH}_{4}$ and $\mathrm{NO}_{3}$ relative to the much smaller pool of $\mathrm{NO}_{2}$ further suggest that the conversion of $\mathrm{NO}_{2}$ to $\mathrm{NO}_{3}$ proceeded rapidly and with a high $\mathrm{NO}_{2}$ affinity. Ward (1984) observed that nitrifica- 
tion increased linearly with $\mathrm{NH}_{4}$ abundance and did not saturate at concentrations $>4 \mathrm{mmol} \mathrm{m} \mathrm{m}^{-3}$. High rates of nitrification within the platelet layer would also help explain why rates of seawater exchange between the platelet ice and the water column were so much greater when $\mathrm{NO}_{3}$ was used as a tracer. For example, Eq. (2) assumes that the production of the $\mathrm{NO}_{3}$ tracer within the platelet layer was zero. If this were not the case and rates of nitrification were substantial, $\Gamma$ calculated from $\mathrm{NO}_{3}$ would be too high. This is exactly what was found in the platelet ice in 1989. $\Gamma$ calculated from $\mathrm{NO}_{3}$ was an order of magnitude greater than estimates obtained from the more conservative tracer $\mathrm{Si}(\mathrm{OH})_{4}$. Although the evidence for nitrification in platelet ice is still far from conclusive, these results suggest that this could be a fruitful area for future research.

Acknowledgements. We thank S. Kottmeier and APA for their logistical support while in McMurdo Sound. We extend special thanks to J. Welborn for his assistance in the field and for HPLC sugar and amino acid analyses, and to $\mathrm{K}$. Buck for counting our protist samples. We are especially grateful to S. Ackley who introduced us to the concept of Darcy flow and to D. Hammond and J. Kremer who helped with the reaction-diffusion model calculations. This work was supported by NSF grants DPP8717237 and DPP-8717692 from the Division of Polar Programs to C.W.S, by ONR grant N00014-0187 to C.W.S, and NASA/Ocean Biogeochemistry RTOP 579-11-07-20 to K.R.A.

\section{LITERATURE CITED}

Arrigo KR, Kremer JN, Sullivan CW (1993a) A simulated Antarctic fast-ice ecosystem. J geophys Res 98:6929-6946

Arrigo KR, Robinson DH, Sullivan CW (1993b) A high resolution study of the platelet ice ecosystem in McMurdo Sound, Antarctica: photosynthetic and bio-optical characteristics of a dense microalgal bloom. Mar Ecol Prog Ser 98:173-185

Azam F, Fenchel T, Field JG, Gray JS, Meyer-Reil LA, Thingstad $F$ (1983) The ecological role of water-column microbes in the sea. Mar Ecol Prog Ser 10:257-263

Barry JP, Dayton PK (1988) Current patterns in McMurdo Sound, Antarctica and their relationship to local biotic communities. Polar Biol 8:367-376

Biggs DC, Amos AF, Holm-Hansen O (1985) Oceanographic studies of epi-pelagic ammonium distributions: the Ross Sea $\mathrm{NH}_{4}{ }^{+}$flux experiment. In: Siegfried WR, Condy PR, Laws RM (eds) Antarctic nutrient cycles and food webs. Springer, Berlin, p 93-103

Bindschadler R (1990) SeaRISE: a multidisciplinary research initiative to predict rapid changes in global sea level caused by collapse of marine ice sheets. NASA Conference Publication 3075. Office of Management, Scientific and Technical Division, Washington, DC

Bock E (1965) Vergleichende Untersuchung über die Wirkung sichtbaren Lichtes auf Nitrosomas europea und Nitrobacter winogradskyi. Arch Mikrobiol 51:18-41

Bunt JS (1964) Primary productivity under sea ice in Antarctic waters. I. Concentrations and photosynthetic activities of microalgae in the waters of McMurdo Sound, Antarctica. Antarct Res Ser 1:13-26

Cota GF, Horne EPW (1989) Physical control of arctic ice algal production. Mar Ecol Prog Ser 52:111-121
Cota GF, Sullivan CW (1990) Photoadaptation, growth and production of bottom ice algae in the Antarctic. J Phycol $26: 399-411$

Dayton PK, Rebilliard GA, DeVries AL (1969) Anchor ice formation in McMurdo Sound, Antarctica, and its biological effects. Science 163:273-274

Dieckmann GS, Arrigo KR, Sullivan CW (1992) A high resolution sampler for nutrient and chlorophyll a profiles of the sea ice platelet layer and underlying water column below fast ice in polar oceans: preliminary results. Mar Ecol Prog Ser 80:291-300

Eide L, Martin S (1975) The formation of brine drainage features in young sea ice. J Glaciol 14: 137-154

Fuhrman JA, Ammerman JW, Azam F (1980) Bacterioplankton in the coastal euphoric zone: distribution, activity and possible relationships with phytoplankton. Mar Biol 60:201-207

Garrison DL, Sullivan CW, Ackley SF (1986) Sea ice microbial community studies in the Antarctic. BioSci 36:243-250

Gilmour AE, MacDonald WPJ, VanderHoeven FG (1960) Ocean currents in McMurdo Sound. Nature 40:867

Gilmour AE, MacDonald WPJ, VanderHoeven FG (1962) Winter measurements of sea currents in McMurdo Sound. NZ J Geol Geophys 5:778-789

Gosselin M, Legendre L, Therriault JC, Demers S (1990) Light and nutrient limitation of sea-ice microalgae (Hudson Bay, Canadian Arctici. J Phycol 26:220-232

Grossi SM, Kottmeier ST, Moe RL, Taylor GT, Sullivan CW (1987) Sea ice microbial communities. VI. Growth and production in bottom ice under graded snow cover. Mar Ecol Prog Ser 35:153-164

Grossi SM, Kottmeier ST, Sullivan CW (1984) Sea ice microbial communities. III. Seasonal abundance of microalgae and associated bacteria. McMurdo Sound, Antarctica. Microb Ecol 10:231-242

Harrison WG, Cota GF, Smith REH (1990) Nitrogen utilization in ice algal communities of Barrow Strait, Northwest Territories, Canada. Mar Ecol Prog Ser 67:275-283

Heath RA (1977) Circulation across the ice shelf in McMurdo Sound, Antarctica. In: Dunbar MJ (ed) Polar oceans. Proc Polar Oceans Conf. Arctic Institute of North America, Calgary, p 129-149

Hobbie JE, Daley RJ, Jaspar S (1977) Use of nuclepore filters for counting bacteria by fluorescence microscopy. Appl environ Microbiol 33:1225-1228

Holdsworth G (1977) Tidal interaction with ice shelves. Annls Géophys 33:133-146

Hoshiai T (1981) Proliferation of ice algae in the Syowa Station area, Antarctica. Mem natn Inst Polar Res Ser E 34: $1-12$

Jacques G (1983) Some ecophysiological aspects of the antarctic phytoplankton. Polar Biol 2:27-33

Johannes RE (1965) Influence of marine protozoa on nutrient regeneration. Limnol Oceanogr 10:434-442

Kipfstuhl J (1991) On the formation of underwater ice and the growth and energy budget of the sea ice in Atka Bay, Antarctica. Rep Polar Res 85:1-88

Kottmeier ST, Grossi SM, Sullivan CW (1987) Sea ice microbial communities. VIII Bacterial production in annual sea ice of McMurdo Sound, Antarctica. Mar Ecol Prog Ser 35: $175-186$

Kottmeier ST, Sullivan CW (1988) Sea ice microbial communities. IX. Effects of temperature and salinity on metabolism and growth of autotrophs and heterotrophs. Polar Biol 8: 293-304

Kottmeier ST, Sullivan CW (1990) Bacterial biomass and production in pack ice of Antarctic marginal ice edge zones. Deep Sea Res 37(8):1311-1330 
Lake RA, Lewis EL (1970) Salt rejection by sea ice during growth. J geophys Res 75:583-590

Larsson U, Hagström Å (1982) Fractionated phytoplankton primary production, exudate release and bacterial production in a Baltic eutrophication gradient. Mar Biol 67 : $57-70$

Lewis EL, Perkin RG (1985) The winter oceanography of McMurdo Sound, Antarctica. In: Jacobs SS (ed) Oceanology of the Antarctic Continental Shelf. Ant Res Ser 43: $145-166$

Lignell R (1990) Excretion of organic carbon by phytoplankton: its relation to algal biomass, primary productivity and bacterial secondary productivity in the Baltic Sea. Mar Ecol Prog Ser 68:85-99

Lindroth P, Mopper K (1979) High performance liquid chromotography determination of subpicomole amounts of amino acids by precolumn derivitization with o-phthaldiadehyde. Analyt Chem 51:1667-1674

Lizotte MP, Sullivan CW (1992) Biochemical composition and photosynthate distribution in sea ice microalgae of McMurdo Sound, Antarctica: evidence for nutrient stress during the spring bloom. Ant Sci 4:23-30

MacAyeal DR (1984) Thermohaline circulation below the Ross Ice Shelf: a consequence of tidally induced vertical mixing and basal melting. J geophys Res 89:597-606

MacAyeal DR (1985) Tidal rectification below the Ross Ice Shelf, Antarctica. In: Jacobs SS (ed) Oceanology of the Antarctic continental shelf. Ant Res Ser 43:109-132

Mopper K, Shultz CA, Cherolot L, Germain C, Revuelta R, Dawson R (1992) Determination of sugars in unconcentrated seawater and other natural waters by liquid chromatography and pulsed amperometric detection. Environ Sci Tech 26:133-138

Müller-Nuglück M, Engel H (1961) Photoinaktivierung von Nitrobacter winogradskyi Buch. Arch Mikrobiol 39 : $130-138$

Niedrauer TM, Martin S (1979) An experimental study of brine drainage and convection of young sea ice. J geophys Res $84: 1176-1186$

Palmisano AC, SooHoo JB, SooHoo SL, Kottmeier ST, Craft LL, Sullivan CW (1986) Photodaptation in Phaeocystis pouchetii advected beneath annual sea ice in McMurdo Sound, Antarctica. J Plankton Res 8: 891-906

Palmisano AC, Sullivan CW (1983) Sea ice microbial communities (SIMCO). I. Distribution, abundance, and primary production of ice microalgae in McMurdo Sound, Antarctica in 1980. Polar Biol 2:171-177

Palmisano AC, Sullivan CW (1985) Pathways of photosynthetic carbon assimilation in sea-ice microalgae from

This article was submitted to the editor
McMurdo Sound, Antarctica. Limnol Oceanogr 30: $674-678$

Parsons TR. Miata Y, Lalli CM (1984) A manual of chemical and biological methods for seawater analysis. Pergamon Press, New York

Reeburgh WS (1984) Fluxes associated with brine motion in growing sea ice. Polar Biol 3:29-33

Schlichting GH (1979) Boundary layer theory, 7th edn. McGraw-Hill, New York

Smetacek V, Scharek R, Gordon LI, Eicken H, Fuhrbach E, Rohardt G, Moore S (1992) Early spring phytoplankton blooms in ice platelet layers of the southern Weddell Sea, Antarctica. Deep Sea Res 39:153-168

Smith REH, Anning J, Clement P, Cota G (1988) Abundance and production of ice algae in Resolute Passage, Canadian Arctic. Mar Ecol Prog Ser 48:251-263

Sommer U (1986) Nitrate and silicate-competition among antarctic phytoplankton. Mar Biol 91:345-351

Stoecker DK, Buck KR, Putt M (1992) Changes in the sea-ice brine community during the spring-summer transition, McMurdo Sound, Antarctica. I. Photosynthetic protists. Mar Ecol Prog Ser 84:265-278

Sullivan CW, Palmisano AC (1984) Sea ice microbial communities: distribution, abundance, and diversity of ice bacteria in McMurdo Sound, Antarctica, in 1980. Appl environ Microbiol 47:788-795

Sullivan CW, Palmisano AC, Kottmeier ST, Girossi SM, Moe R (1985) The influence of light on growth and development of the sea-ice microbial community of McMurdo Sound. In: Siegfried WR, Condy PR, Laws RM (eds) Antarctic nutrient cycles and food webs. Springer Verlag, Berlin, p $78-83$

Ward BB (1984) Combined autoradiography and immunofluorescence for estimation of single cell activity of ammonium-oxidizing bacteria. Limnol Oceanogr 29:402-410

Ward BB, Olson RJ, Perry MJ (1982) Microbial nitrification rates in the primary nitrite maximum off Southern California. Deep Sea Res 29:247-255

Welch HE, Bergmann MA (1989) Seasonal development of ice algae and its prediction from environmental factors near Resolute, NWT, Canada. Can J Fish Aquat Sci 46 . 1793-1804

Williams PJ leB (1990) The importance of losses during microbial growth: commentary on the physiology, measurement and ecology of release of dissolved organic material. Mar microb Food Webs 4:175-206

Wood AM, Van Valen LM (1990) Paradox lost? On the release of energy-rich compounds by phytoplankton. Mar microb Food Webs 4:103-116

Manuscript first received: October 11, 1994

Revised version accepted: April 4, 1995 